\title{
CSR Contribution made by selected Indian Manufactur ing Multinational Companies
}

\author{
Miss. Charuta P. Kulkarni \\ Chhatrapati Shahu Institute of Business Education and Research, Kolhapur, Maharashtra, India
}

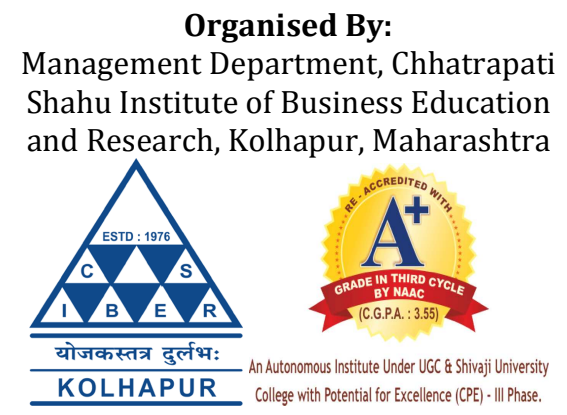

How to cite this paper: Miss. Charuta P. Kulkarni "CSR Contribution made by selected Indian Manufacturing Multinational Companies" Published in International Journal of Trend in Scientific Research and Development (ijtsrd), ISSN: 2456-6470, Special Issue | Fostering Innovation, Integration and Inclusion Through Interdisciplinary

Practices in Management, March 2019, pp.27-31, URL: https://www.ijtsrd.c om/papers/ijtsrd23 055.pdf

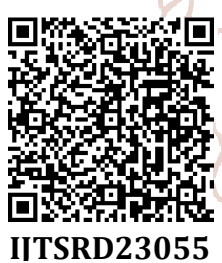

\section{INTRODUCTION}

Corporate Social Responsibility aimed at encouraging companies to be aware of their business on society, their own stakeholders and the environment. CSR is business activity which contributes to sustainable development by providing economic, social and environmental benefits to the stakeholders. CSR may not be beneficial in short run but promote positive social and environmental change.

The CSR committee mentioned the guiding principle under section 135 of the Companies Act, 2013 as follows," CSR is the process by which an organization thinks about and evolves its relation with stakeholders for the common good, and demonstrates its commitment in this regard by adoption of appropriate business processes and strategies. Thus CSR is not charity or donations. CSR is a way of doing business, by which corporate entities visibly contribute to the social good. Socially responsible companies do not limit themselves to use resources to engage in activities that increase only their profits. They use CSR to integrate economic, social and environmental objectives with the company's operations and growth."

\section{ABSTRACT} 2013 Companies mentioned. The rationale behind CSR is to embrace the responsibility for companies' action and encouraging the positive impact through its activities on present study has made, livelihood, rural development, education and so on. The made by four major companies in India. All the data collected and used for research work is secondary in nature like official websites and reports published by companies, magazines, journals and other reference books. The purpose of this paper is to know the contribution made by four top Indian manufacturing MNC and analyze the same. These companies are drawn from 'The CSR Journal'

KEYWORDS: Corporate Social Responsibility, Triple Bottom Line, Companies Act

\section{Applicability of CSR}

1. Section 135(1)of the Company Act 2013 mandates the CSR expenditure for the following companies. Every company having

A. Minimum net worth of rupees five hundred crore,

B. Minimum turnover of rupees one thousand crore,

C. Minimum Net profit of rupees five crore.

shall constitute a Corporate Social Responsibility Committee of the board consisting minimum three directors including at least one independent director.

2. The board's report under 134(3) shall disclose the composition of the CSR committee.

3. Functions of CSR committee is

A. to formulate and recommend to the board, a CSR policy which shall indicate the activities to be undertaken as specified under schedule VII

B. to suggest the amount of expenditure to be incurred

C. to monitor CSR policy of the company time to time. 
International Journal of Trend in Scientific Research and Development (IJTSRD) @ www.ijtsrd.com eISSN: 2456-6470

4. The board of every company referred in sub-section (1) shall,

A. approve the CSR policy for the company and disclose contents of such policy in its report and also place it on the company's website after taking into account the recommendation made by the CSR committee

B. ensure that the activities as are included in CSR policy are undertaken by the company.

5. every company shall ensure that the company spends at least two percent of the average net profit of the company made during the three immediately preceding financial years.

\section{Triple Bottom Line}

The concept was introduced by John Elkington in 1994. It measures company's degree of economical value as well as environmental impact and social responsibility. Companies are beginning to realize that it is not sufficient to rely on financial profit alone for survival. It should ensure that their activities of the business are impacting the society in a positive way.

Normally the company's bottom line on its income statement is its net profit earned during the year, but as per the concept of the TBL focus of the company is extended beyond profits which include social as well as environmental issues to measure the actual cost of doing business. In short it consists of three parts i.e. social, environmental and financial. Some companies adopt this approach to assess their performance in broader perspective and increase the value of the business.

\section{Review of Literature}

Gatyatri Prabhakaran and Ansuman Panda in their research paper," The CSR activities adopted by IT firms in Bengaluru" emphasis on exploring and comparing the several expenditure made by IT firm in Bangalore in CSR. They concluded that, rather than seeing how much amount was spend by the companies, one should focus more on where they spent and what outcome of it.

Nidhi Tandon and Simran Kaur in their research paper, "Role of Corporate Social Responsibility in India" has thrown a light on reasons for growth of CSR in India and to know what are potential advantages of CSR to the companies and finally concluded that companies which comes under SME sector planning to introduce CSR as a strategy to increase their reach to remote areas.

Omweno Nyameyio Enock and Dr. Kunda Basavraj in their study, 'Corporate Social Responsibility of Tata Company and ITC Company: Comparative Study' focused on benefits followed by CSR. Chi square test was used to test the hypothesis and further the paper concluded that CSR is inevitable and is part of inclusive and wider sustainable development goal.

D. S. Pratima have attempted to cover the questions like whether company have any policy, is there committee which looks after the CSR policyand lastly wheter it cover all the sectors.

\section{Objectives}

1. To understand the concept of Corporate Social Responsibility

2. To study legal aspect of Corporate Social Responsibility

3. To analyze contribution made by selected companies in different sectors.

\section{Methodology}

This whole study is based on Secondary sources of the data The data is collected from Companies' Annual reports, Sustainability reports. In addition to that, several websites are also visited by researcher. Journals and articles have been referred for background study.

CSR contribution made by the companies in various sectors

\begin{tabular}{|c|c|c|c|c|c|c|c|c|}
\hline \multirow[b]{2}{*}{$\begin{array}{c}\text { Sectors in which } \\
\text { projects are } \\
\text { covered }\end{array}$} & \multicolumn{2}{|c|}{ Tata Chemicals } & \multicolumn{2}{|c|}{ Mahindra and Mahindra } & \multicolumn{2}{|c|}{ Tata Motors } & \multicolumn{2}{|c|}{ Tata Power } \\
\hline & $\begin{array}{l}\text { Amount } \\
\text { spend in } \\
\text { crore } \\
\end{array}$ & $\begin{array}{c}\text { Amount } \\
\text { spend in } \\
\% \\
\end{array}$ & $\begin{array}{l}\text { Amount } \\
\text { spend in } \\
\text { crore }\end{array}$ & $\begin{array}{c}\text { Amount } \\
\text { spend in } \\
\% \\
\end{array}$ & $\begin{array}{l}\text { Amount } \\
\text { spend in } \\
\text { crore } \\
\end{array}$ & $\begin{array}{c}\text { Amount } \\
\text { spend in } \\
\% \\
\end{array}$ & $\begin{array}{c}\text { Amount } \\
\text { spend in } \\
\text { crore } \\
\end{array}$ & $\begin{array}{c}\text { Amount } \\
\text { spend in } \\
\% \\
\end{array}$ \\
\hline Education & 4.47 & 31 & 35.43 & 43 & 10.43 & 49 & 0.62 & 4 \\
\hline $\begin{array}{c}\text { Environmental } \\
\text { Sustainability }\end{array}$ & 4.63 & 32 & 7.78 & 9 & 1.38 & 6 & 0.22 & 1 \\
\hline $\begin{array}{c}\text { Health care, } \\
\text { nutrition, } \\
\text { Sanitation and } \\
\text { Safe drinking } \\
\text { water }\end{array}$ & 1.87 & 13 & 9.92 & 12 & 3.5 & 16 & 1.09 & 7 \\
\hline $\begin{array}{c}\text { Poverty } \\
\text { alleviation, } \\
\text { livelihood } \\
\text { enhancement, } \\
\text { infrastructure } \\
\text { support, } \\
\text { empowering } \\
\text { women }\end{array}$ & 2.21 & 15 & 10.14 & 12 & 4.52 & 21 & 8.19 & 56 \\
\hline $\begin{array}{c}\text { Rural } \\
\text { Devepopement }\end{array}$ & & 0.00 & 15.91 & 19 & 1 & 5 & 1.29 & 9 \\
\hline $\begin{array}{c}\text { Protection of } \\
\text { national heritage, } \\
\text { art and culture }\end{array}$ & & 0.00 & 2.25 & 3 & - & 0 & - & 0 \\
\hline
\end{tabular}


International Journal of Trend in Scientific Research and Development (IJTSRD) @ www.ijtsrd.com eISSN: 2456-6470

\begin{tabular}{|c|c|c|c|c|c|c|c|c|}
\hline $\begin{array}{c}\text { Promotion of } \\
\text { Sports }\end{array}$ & & 0.00 & 0.26 & 0 & - & 0 & - & 0 \\
\hline $\begin{array}{c}\text { Contribution to } \\
\text { Prime Minister } \\
\text { National Relief } \\
\text { Fund }\end{array}$ & 0.00 & - & 0 & - & 0 & - & 0 \\
\hline $\begin{array}{c}\text { Disaster } \\
\text { Response }\end{array}$ & 0.75 & 5 & 0.29 & 0.4 & - & 0.0 & - & 0.0 \\
\hline Other & 0.35 & 2 & - & 0 & 0.6 & 3 & 3.3 & 22 \\
\hline Total & 14.28 & 100.0 & 81.98 & 100 & 21.43 & 100 & 14.71 & 100 \\
\hline Budgeted CSR/ & 16.8 & & 81.27 & & NA & & 13.71 & \\
\hline $\begin{array}{c}\text { Extra/less CSR } \\
\text { expenditure } \\
\text { incured }\end{array}$ & -2.5 & 0.7 & & - & & 1.0 & \\
\hline $\begin{array}{c}\text { \% of extra CSR to } \\
\text { Prescribed CSR } \\
\text { limit }\end{array}$ & & & 0.87 & & - & & 7.29 & \\
\hline
\end{tabular}

Researcher have drawn some common sectors in which companies generally contribute their funds to comply with CSR policy as per Companies Act,2013. But now as CSR is not just remained charity or donation and seen as business strategy for long term value creation of company, they (companies) are not seen to incur the exact amount of CSR limit which is calculated as per companies act, 2013 (i.e. $2 \%$ of average net profit of preceding three years) but more contribution is made by the companies.

Researcher has analyzed the CSR contribution made by companies separately.

Tata Chemicals

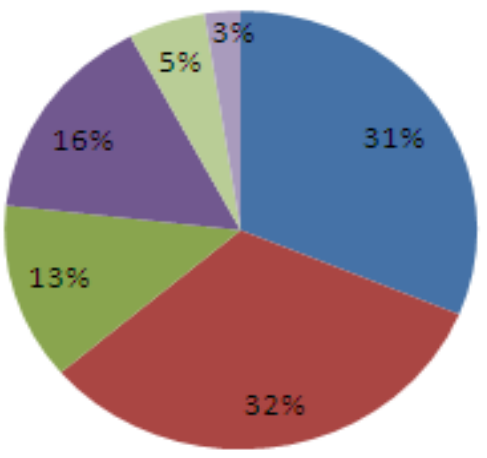

Education

Environmental Sustainability

- Health care, nutrition, Sanitation and Safe drinking water

Poverty alleviation, livelihood enhancement, infrastructure support, empowering women

Rural Devepopement

Protection of national heritage, art and culture

Promotion of Sports

Contribution to Prime Minister National Relief Fund

Disaster Response

Other

Tata Chemical Limited is an global company manufactures chemicals, consumer products and crop nutrition having headquarter in Mumbai, India. The company is a subsidiary of the Tata Group conglomerate.

Tata Chemical have incurred more of its CSR funds on "Poverty alleviation Programs" and "infrastructure support programs" $(15 \%)$, health care and drinking water, sanitation project (13\%). On education and environment it has expended $31 \%$ and $32 \%$ of total amount respectively and 5\% on disaster response. Most of the projects of CSR are held in Mithapur(Gujarat), Barbala(Uttar Pradesh), Haldia(West Bengal), Mumbai(Maharashtra).

As per the Companies Act, 2013, prescribed CSR was rupees 16.8 crore while company has spend 14.28 crore on the project and rupees 2.52 crore were unspent. Further company have given explanationin its Statutory report that out of unspent amount of rupees 2.52 crore rupees 1.7 crore was spent in the month of April 2018 and balance amount of rupees 0.82 crore will be spent in FY 18-19 as agrredby the board. 
International Journal of Trend in Scientific Research and Development (IJTSRD) @ www.ijtsrd.com eISSN: 2456-6470

\section{Mahindra and Mahindra}
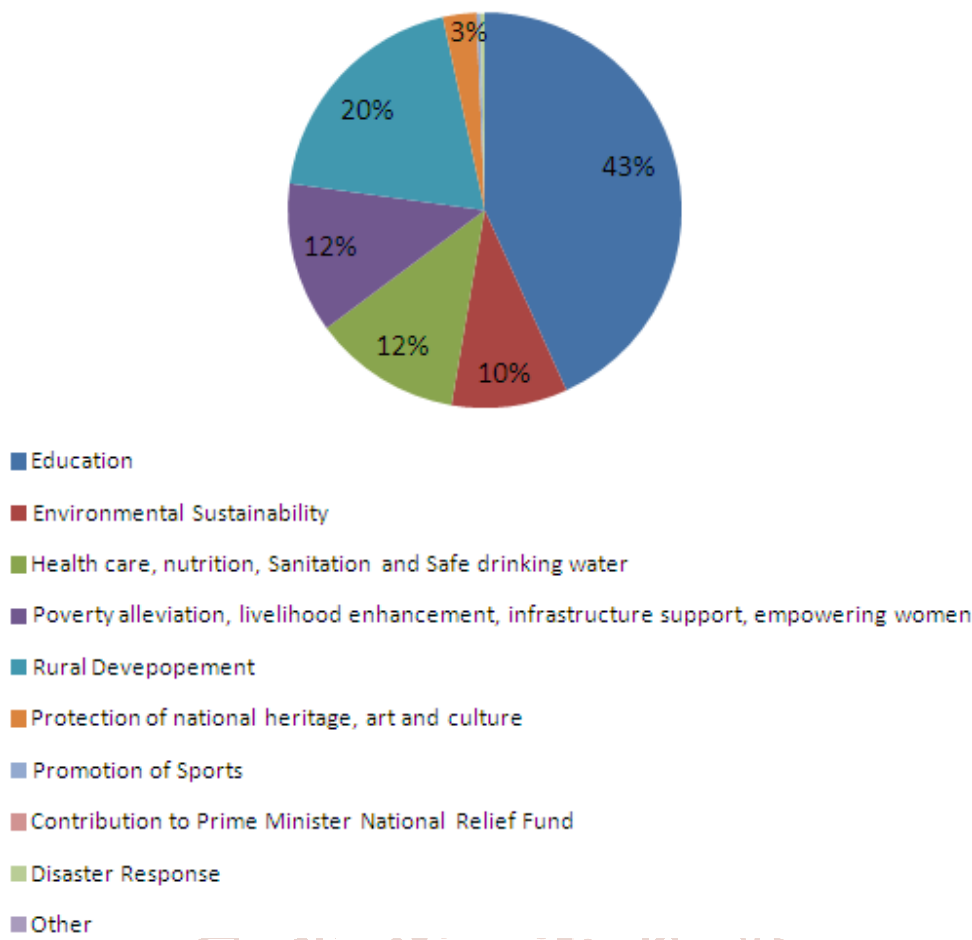

Mahindra and Mahindra ltd. is an Indian multinational car manufacturing corporation having headquartered in Mumbai, Maharashtra, India which was established in 1945 as Mohammad and Mahindra and later renamed as Mahindra and Mahindra. It is one of the largest car manufacturer in India and largest tractor manufacturer in the world. It is also part of Mahindra group which Indian conglomerate.

Mahindra and Mahindra has total expenditure on CSR is rupees 81.98 crore out of which $43 \%$ of the total amount spend on education (in almost every state of the India) and 19\% on rural development. $12 \%$ of the total amount incurred on healthcare and sanitation as well as on Livelihood enhancement and poverty alleviation. Lastly $9 \%$ of the total amount is spend on environmental sustainability and $3 \%$ on protection of national heritage, art and culture.

Prescribed CSR of the company was rupees 81.27 crore and actual expenditure is rupees 81.98 crore which is $0.7 \%$ more than prescribed CSR.

\section{Tata Motors}
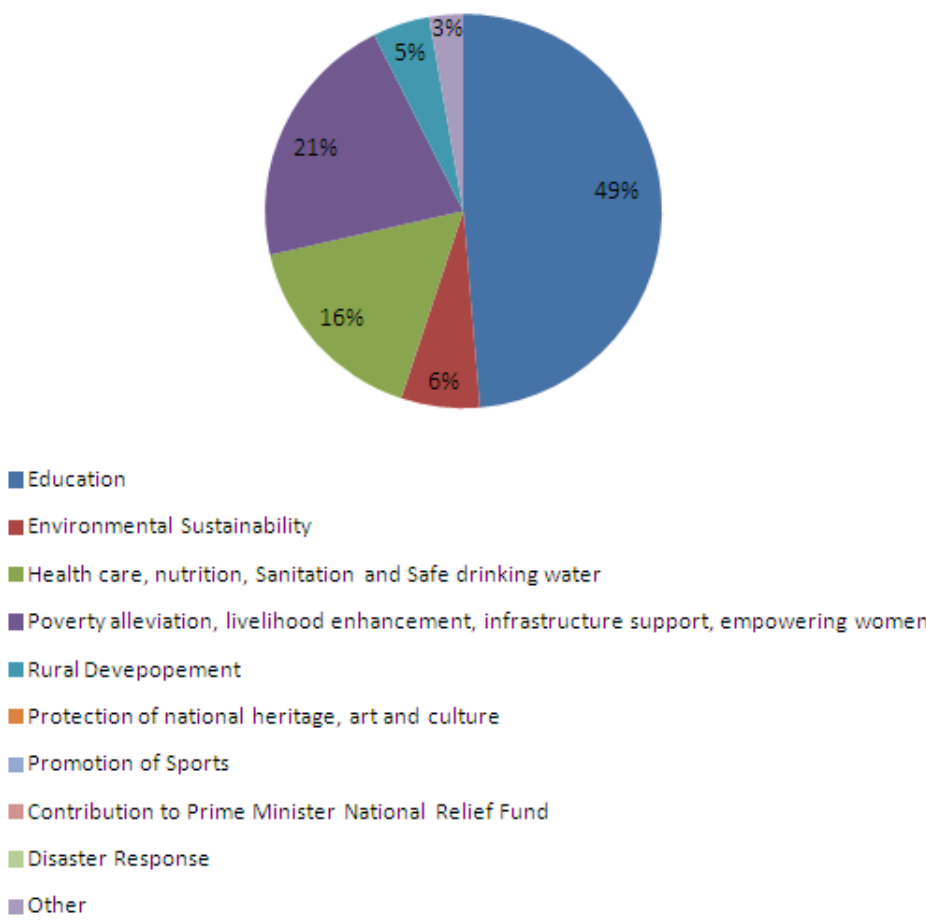
International Journal of Trend in Scientific Research and Development (IJTSRD) @ www.ijtsrd.com eISSN: 2456-6470

Tata Motors having headquartered in Mumbai is a subsidiary of Tata Group, an Indian conglomerate company. It manufactures buses, vans, trucks, cars, construction equipments and military vehicles.

Tata Motors has spend total rupees 21.43 crore out of which $49 \%$ spent on Education alone, $21 \%$ on employability enhancing skill development, $16 \%$ on healthcare in Karnataka, Maharashtra, U.P., Uttarakhand. Further $6 \%$ and $5 \%$ are spent on environmental sustainability and rural development respectively.

Due to losses suffered by the company in previous years it was not liable for CSR expenditure still have incurred rupees 21.43 crore.

Tata Power
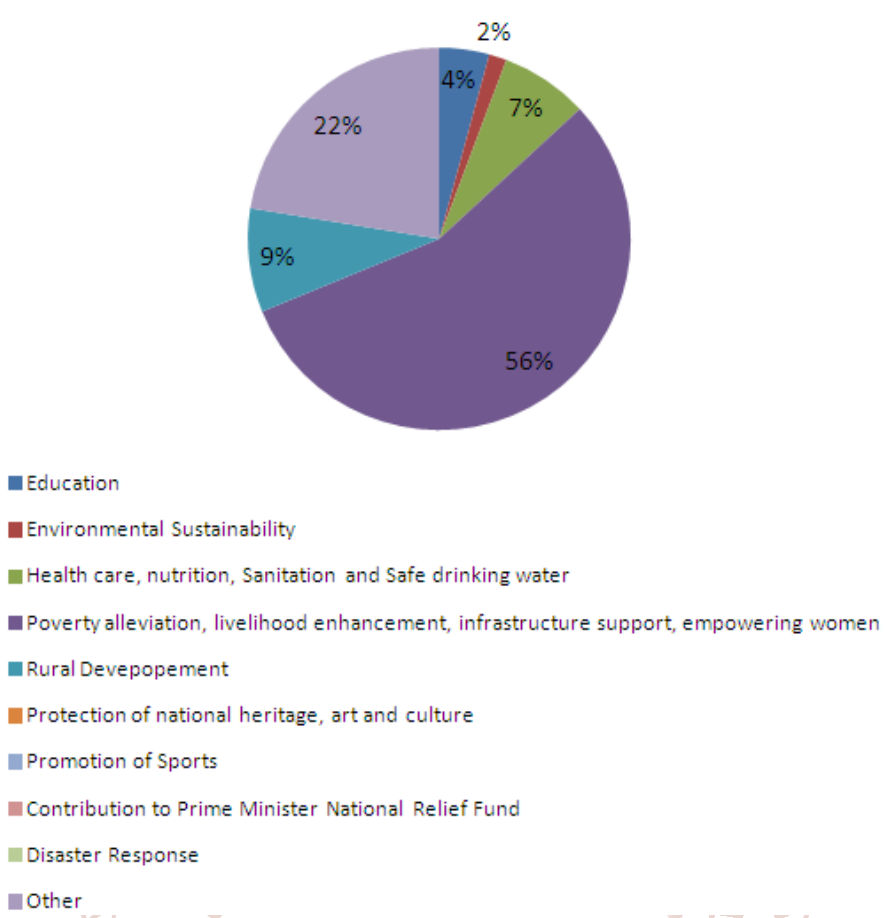

Tata Power Limited is an Indian company based in Mumbai, Maharashtra, India and is part of the Tata group. Main business activity of the company is to generate, distribute and transmit the electricity. It is India's largest integrated power company with the installed capacity of 10577MW.

Tata Power spend $56 \%$ of its total expenditure on CSR towards poverty alleviation and livelihood enhancement, $22 \%$ in miscellaneous areas, $9 \%$ on rural development. $7 \%$ and $1 \%$ spend on healthcare, sanitation and environmental sustainability respectively.

Prescribed limit of CSR for the company was rupees 13.71 crore and actual expenditure is rupees 14.71 crore which approximately $7 \%$ more than prescribed amount.

\section{Conclusion}

The present societal marketing concept is evolving which have given the birth to CSR. Of course it also has some legal aspect to comply with but the influence of CSR activities cannot be neglected. Many corporations now have realized the importance of being connected with the stakeholders for their goodwill, reputation and long term value enhancement of the company.

The main objective of the paper is to point out the disbursement of CSR funds by the companies toward various sectors like education, healthcare, rural development, livelihood enhancement and so on. For this purpose top four manufacturing companies in CSR are selected as per "The CSR Journal". It is concluded from following discussion that all the companies have delivered their responsibility by contributing CSR funds in various sectors even more than their prescribed limit except Tata Chemicals. It indicates that CSR is not just considered as legal compliance but a noble and strategic way to give rise to societal, environmental and economical enrichment.

\section{Reference}

[1] https://thecsrjournal.in/csr-top-10-responsiblebusiness-rankings-2018/

[2] https://www.tatachemicals.com/upload/content_pdf/ta ta-chemicals-yearly-reports-2017-18.pdf

[3] https://www.tatapower.com/pdf/investorrelations/99Annual-Report-2017-18.pdf

[4] https://www.mahindra.com/resources/investorreports/FY18/Announcements/Mahindra-andMahindra-Annual-Report-2017-2018.pdf

Copyright (C) 2019 by author(s) and International Journal of Trend in Scientific Research and Development

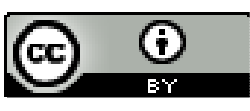
Journal. This is an Open Access article distributed under the terms of the Creative Commons Attribution License (CC BY 4.0) (http://creativecommons.org/licenses/by/4.0) 